\title{
Empirical Study on the Point system of Urban Household Garbage Classification in China -- Taking Hangzhou as an example
}

\author{
XU Zheng ${ }^{1, \text { a }}$ \\ ${ }^{1}$ Economics and Management School of Hangzhou Normal University, HangZhou, ZheJiang, \\ 311121 China \\ a562982601@qq.com
}

Keywords: Hangzhou; urban household garbage classification and recycling; point system; circular economy

\begin{abstract}
With the gradual improvement of China's economic development, residents' household garbage increase with rapid growth, which not only endangers the environment and people's health, but also poses a major threat to the social and economic development. The management of "garbage besieged city" is urgent, and it is the premise to deal with the problem of "garbage besieged city" to conduct household garbage classification and recycling. Garbage classification and recycling is a specific operation to improve the efficiency of resource utilization. It not only effectively improves the environmental quality, but also conforms to the concept of circular economy and realizes sustainable development. The classification and recycling of household garbage is a comprehensive interdisciplinary subject, which must combine the theoretical knowledge and practical experience in multiple fields. As a famous tourist city and Yangtze river delta center city, Hangzhou actively works on household garbage classification and explores the point system with innovation, which can stimulate the enthusiasm of the residents and set up the awareness of garbage classification, in order to promote the development of circular economy and to achieve the goals of sustainable development at last. The paper chooses this proposition to explore the significance of the point system of garbage classification and recycling in Chinese cities.
\end{abstract}

\section{Introduction}

The management of urban household garbage is often used as an indicator of urban governance and even a sign of good governance of a city. Economic development, urbanization and improvement of living standards lead to the increase of both the quantity and the complexity of garbage production; household garbage is the main source of urban garbage, occupying the most part of cost of urban environmental renovation. In France, the government investment in the field of waste disposal is as much as $33 \%$ of the total investment of the whole environmental control. However, landfill and incineration, as the primary means for urban garbage disposal, cannot keep pace with the growth of the garbage production; therefore, the fundamental way out lies in the "reduction" and "recycling", in which the source classification of garbage improves the recycling utilization of garbage and reduces the garbage transportation cost and difficulty of end treatment. In developed countries, garbage management has been very effective; and in some areas, the volume of garbage production has not increased with the increase of population. China is the world's largest garbage producer, and it still maintains an annual growth rate of $8 \%$ to $10 \%$. Today, more than two-thirds of the country's cities are trapped in the "garbage city", and many cities have no place to fill them. Garbage classification is a complex process, and the recycling rate is affected by many factors, both macro factors such as policy and social environmental factors, and the micro factors such as residents' individual factors, including values, the popularity of garbage classification knowledge, etc. However, the domestic literature in the field of study is very rare, both the lack of theoretical framework, and the lack of a large sample of empirical research; through visiting the 
municipal solid waste disposal regulation center, the municipal sanitation supervision center, the municipal legislative affairs office, this research makes analysis on the implementation statuse of point system of household garbage classification, finds out the problems in it, and puts forward solutions to solve these problems, so as to improve the point system of Hangzhou household garbage point system, optimize the urban household garbage management, and promote the development of circular economy.

\section{Empirical analysis of the point system of urban household garbage classification.}

A. Rules of the point system of Hangzhou household garbage classification

The bonus point amount of collected garbage classification by residents is mainly determined by the type of household garbage and its weight. The article 14 of Hangzhou Urban Household Garbage Management Regulations stipulates the standards of living garbage classification, mainly divided into four categories of recycling waste, kitchen waste, hazardous waste and other waste. At present, there are several types of live garbage that can be redeemed for recyclable garbage and hazardous waste in the Green Point Website.

Table 1 Point table of household collected garbage classification

\begin{tabular}{|c|c|c|c|c|}
\hline Category & Type & Product & Unit & Points \\
\hline \multirow{8}{*}{$\begin{array}{l}\text { Solid } \\
\text { waste } \\
\text { (Glass) }\end{array}$} & \multirow{4}{*}{$\begin{array}{l}\text { Colored } \\
\text { glass }\end{array}$} & Beer bottles & $\mathrm{kg}$ & 30 \\
\hline & & Rice wine bottles & $\mathrm{kg}$ & 20 \\
\hline & & Red wine bottles & $\mathrm{kg}$ & 15 \\
\hline & & Colored glass vessels & $\mathrm{kg}$ & 15 \\
\hline & \multirow{3}{*}{$\begin{array}{l}\text { Colorless } \\
\text { glass }\end{array}$} & White spirit bottles, canned bottles & $\mathrm{kg}$ & 20 \\
\hline & & Glasses, white glass & $\mathrm{kg}$ & 20 \\
\hline & & $\begin{array}{l}\text { Ashtray, white glassware automobile glass, } \\
\text { steel tea table. }\end{array}$ & $\mathrm{kg}$ & 20 \\
\hline & $\begin{array}{l}\text { Tempered } \\
\text { glass }\end{array}$ & Desks and chairs & $\mathrm{kg}$ & 15 \\
\hline \multirow{3}{*}{$\begin{array}{l}\text { Hazardou } \\
\text { s waste } \\
\text { (light } \\
\text { source } \\
\text { with } \mathrm{Hg} \text { ) }\end{array}$} & \multirow{3}{*}{$\begin{array}{c}\text { Various } \\
\text { modulator } \\
\text { tubes }\end{array}$} & Energy-saving lamp tubes & $\mathrm{kg}$ & 10 \\
\hline & & Spotlights, neon lights, etc. & $\mathrm{kg}$ & 10 \\
\hline & & Fluorescent tubes, incandescent bulbs. & $\mathrm{kg}$ & 10 \\
\hline \multirow{4}{*}{$\begin{array}{l}\text { Hazardou } \\
\text { s waste } \\
\text { (batteries) }\end{array}$} & $\begin{array}{l}\text { Telephone } \\
\text { batteries }\end{array}$ & Nickel fluoride, nickel hydride, His ionic & $\mathrm{kg}$ & 1650 \\
\hline & $\begin{array}{l}\text { Rechargeab } \\
\text { le batteries }\end{array}$ & Ni-Cb, nickel hydride, Lithium-ion & $\mathrm{kg}$ & 1650 \\
\hline & $\begin{array}{l}\text { Lead-acid } \\
\text { cell }\end{array}$ & $\begin{array}{l}\text { Rechargeable battery, battery and other lead } \\
\text { acid. }\end{array}$ & $\mathrm{kg}$ & 1350 \\
\hline & $\begin{array}{l}\text { Ordinary } \\
\text { dry } \\
\text { batteries }\end{array}$ & Alkaline and non-rechargeable. & $\mathrm{kg}$ & 10 \\
\hline \multirow{7}{*}{$\begin{array}{l}\text { Hazardou } \\
\text { S waste } \\
\text { (electrical } \\
\text { waste) }\end{array}$} & \multirow{7}{*}{$\begin{array}{l}\text { Computer } \\
\text { type }\end{array}$} & Mouse, keyboard & Number & 1350 \\
\hline & & Camera, various USB & Number & 1350 \\
\hline & & Memory, floppy drive & Number & 1350 \\
\hline & & Video card & Number & 1350 \\
\hline & & Network card & Number & 1350 \\
\hline & & Router & Number & 650 \\
\hline & & Motherboard, CPU, hard disk, optical drive. & Number & 1350 \\
\hline
\end{tabular}




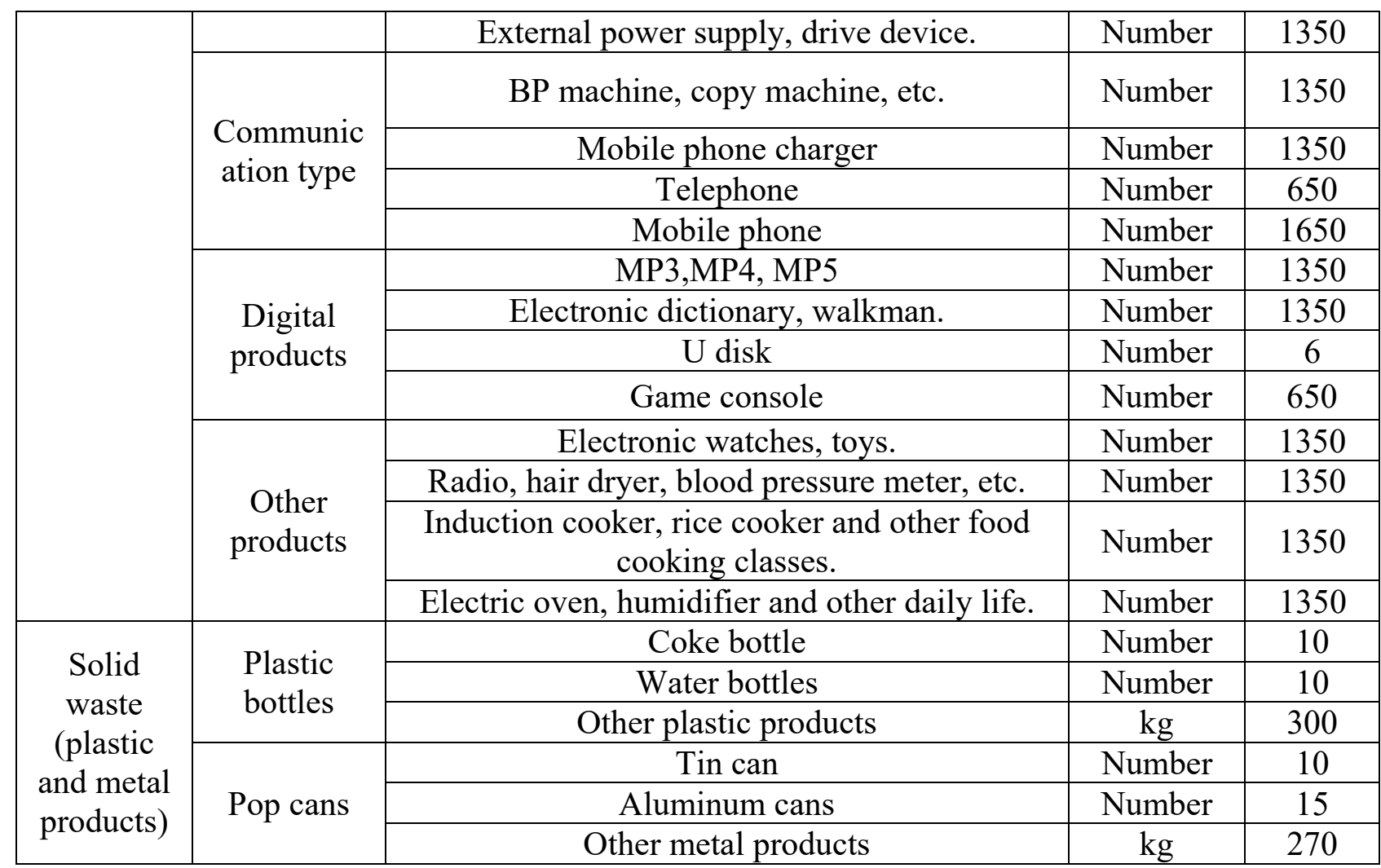

The Green Point Website exchange guide also clarified that any costs incurred during the use of the Green Point Website service will be paid by the points. At the same time, the Green Point Website provides the residents with the distribution services of the point exchange products, which are express delivery and reception at certain service sites. There is no need to pay any fee for the fixed point exchange. As for express delivery, at the same time of the user exchanging for goods, the cost of delivery will be directly generated in the order, and after the user completes the transaction, the points needed for express fee and commodity will be deducted from the user account as a whole. When the total value of a single exchange of goods exceeds 50,000 points, the website system will automatically transfer the points deducted for the express fee to the user account after the transaction is completed. Other after-sale services are also held by the Green Point Website.

Table 2 Descriptive statistics of sample population attributes.

\begin{tabular}{|c|c|c|c|c|c|c|c|}
\hline & $\begin{array}{l}\text { Population } \\
\text { attribute } \\
\text { variable }\end{array}$ & $\begin{array}{l}\text { Populati } \\
\text { on }\end{array}$ & $\begin{array}{l}\text { Proportion } \\
\text { of total } \\
\text { sample } \\
\text { proportion } \\
\quad(\%)\end{array}$ & & $\begin{array}{l}\text { Population } \\
\text { attribute } \\
\text { variable }\end{array}$ & $\begin{array}{c}\text { Populatio } \\
n\end{array}$ & $\begin{array}{l}\text { Proportio } \\
\mathrm{n} \text { of total } \\
\text { sample } \\
\text { proportio } \\
\mathrm{n}(\%)\end{array}$ \\
\hline \multirow{2}{*}{ Gender } & Male & 352 & 47.4 & \multirow{4}{*}{$\begin{array}{l}\text { Educa } \\
\text { tion } \\
\text { level }\end{array}$} & $\begin{array}{l}\text { Never go to } \\
\text { school }\end{array}$ & 8 & 1.1 \\
\hline & Female & 390 & 52.6 & & Primary school & 32 & 4.3 \\
\hline \multirow[b]{2}{*}{ Age } & $<20$ & 6 & 0.8 & & $\begin{array}{c}\text { Junior high } \\
\text { school }\end{array}$ & 98 & 13.2 \\
\hline & $20 \sim 30$ & 196 & 26.4 & & $\begin{array}{l}\text { High school } \\
\text { (secondary } \\
\text { school, } \\
\text { vocational }\end{array}$ & 191 & 25.7 \\
\hline
\end{tabular}




\begin{tabular}{|c|c|c|c|c|c|c|c|}
\hline & & & & & $\begin{array}{c}\text { school, } \\
\text { technical } \\
\text { school, etc.) }\end{array}$ & & \\
\hline & $31 \sim 40$ & 278 & 37.5 & & $\begin{array}{c}\text { Junior college } \\
\text { (higher } \\
\text { vocational) } \\
\end{array}$ & 160 & 21.6 \\
\hline & $41 \sim 50$ & 127 & 17.1 & & $\begin{array}{l}\text { Undergraduate } \\
\text { course }\end{array}$ & 233 & 31.4 \\
\hline & $51 \sim 60$ & 64 & 8.6 & & $\begin{array}{c}\text { Postgraduate } \\
\text { and above }\end{array}$ & 20 & 2.7 \\
\hline & $>60$ & 71 & 9.6 & & $\begin{array}{l}\text { Government } \\
\text { departments, } \\
\text { public } \\
\text { institutions, } \\
\text { military units. }\end{array}$ & 116 & 15.6 \\
\hline & $<5000$ & 95 & 12.8 & & enterprise & 341 & 46 \\
\hline $\begin{array}{c}\text { Total } \\
\text { monthl }\end{array}$ & $\begin{array}{c}5000 \sim 1000 \\
0\end{array}$ & 254 & 34.2 & $\begin{array}{l}\text { Profe } \\
\text { ssion }\end{array}$ & $\begin{array}{l}\text { Social group, } \\
\text { residence/villag } \\
\text { e committee. }\end{array}$ & 23 & 3.1 \\
\hline $\begin{array}{c}\mathrm{y} \\
\text { income }\end{array}$ & $\begin{array}{c}10001 \sim 150 \\
00\end{array}$ & 177 & 23.9 & & Soho & 104 & 14 \\
\hline $\begin{array}{c}\text { after } \\
\text { tax }\end{array}$ & $\begin{array}{c}15001 \sim 200 \\
00\end{array}$ & 113 & 15.2 & & Retired & 78 & 10.5 \\
\hline (yuan) & $\begin{array}{c}20001 \sim 250 \\
00\end{array}$ & 61 & 8.2 & & Other & 80 & 10.8 \\
\hline & $>25000$ & 42 & 5.7 & & & & \\
\hline
\end{tabular}


Table 3 Factor analysis and verification results of measurement items

\begin{tabular}{|c|c|c|c|c|c|c|c|c|c|}
\hline $\begin{array}{l}\text { Public } \\
\text { factor }\end{array}$ & $\begin{array}{c}\text { Measur } \\
\text { ement } \\
\text { index }\end{array}$ & $\begin{array}{l}\text { Factor } \\
\text { loading }\end{array}$ & AVE & $\mathrm{CR}$ & $\begin{array}{l}\text { Public } \\
\text { factor }\end{array}$ & $\begin{array}{c}\text { Measure } \\
\text { ment } \\
\text { index }\end{array}$ & $\begin{array}{l}\text { Factor } \\
\text { loading. }\end{array}$ & AVE & $\mathrm{CR}$ \\
\hline \multirow{8}{*}{$\begin{array}{c}\text { Value } \\
\text { perception }\end{array}$} & PV1 & 0.833 & \multirow{8}{*}{0.88} & \multirow{8}{*}{0.98} & \multirow{8}{*}{$\begin{array}{c}\text { Percept } \\
\text { ual } \\
\text { behavio } \\
r \\
\text { control }\end{array}$} & PBC1 & 0.762 & \multirow{8}{*}{0.73} & \multirow{8}{*}{0.96} \\
\hline & PV2 & 0.784 & & & & PBC3 & 0.722 & & \\
\hline & PV3 & 0.794 & & & & PBC3 & 0.73 & & \\
\hline & PV4 & 0.682 & & & & PBC4 & 0.719 & & \\
\hline & PV5 & 0.788 & & & & PBC5 & 0.504 & & \\
\hline & PV6 & 0.805 & & & & PBC6 & 0.538 & & \\
\hline & PV7 & 0.737 & & & & PBC8 & 0.546 & & \\
\hline & PV8 & 0.63 & & & & PBC10 & 0.572 & & \\
\hline \multirow{9}{*}{$\begin{array}{c}\text { Subjective } \\
\text { norms }\end{array}$} & SN1 & 0.658 & \multirow{5}{*}{0.87} & \multirow{5}{*}{0.98} & \multirow{4}{*}{$\begin{array}{c}\text { The } \\
\text { effectiv } \\
\text { eness of } \\
\text { the } \\
\text { informa } \\
1 \\
\text { recover } \\
y \\
\text { system. }\end{array}$} & IRM1 & 0.655 & \multirow{4}{*}{0.74} & \multirow{4}{*}{0.92} \\
\hline & SN2 & 0.656 & & & & IRM2 & 0.801 & & \\
\hline & SN3 & 0.702 & & & & IRM3 & 0.811 & & \\
\hline & SN4 & 0.683 & & & & IRM4 & 0.803 & & \\
\hline & SN5 & 0.697 & & & \multirow{9}{*}{$\begin{array}{c}\text { Garbage } \\
\text { classific } \\
\text { ation } \\
\text { particip } \\
\text { ation } \\
\text { level. }\end{array}$} & WR1 & 0.803 & \multirow{9}{*}{0.82} & \\
\hline & SN6 & 0.671 & \multirow{4}{*}{0.82} & \multirow{4}{*}{0.98} & & WR2 & 0.834 & & \\
\hline & SN8 & 0.544 & & & & WR3 & 0.838 & & \\
\hline & SN9 & 0.629 & & & & WR4 & 0.925 & & \\
\hline & SN10 & 0.597 & & & & WR5 & 0.934 & & 0.98 \\
\hline \multirow{4}{*}{$\begin{array}{l}\text { Policy } \\
\text { effectiven } \\
\text { ess } \\
\text { perception }\end{array}$} & PPE1 & 0.772 & \multirow{4}{*}{0.88} & \multirow{4}{*}{0.97} & & WR6 & 0.902 & & \\
\hline & PPE2 & 0.779 & & & & WR7 & 0.926 & & \\
\hline & PPE3 & 0.761 & & & & WR8 & 0.874 & & \\
\hline & PPE4 & 0.776 & & & & WR9 & 0.877 & & \\
\hline
\end{tabular}

Based on the analysis results, this paper just extracts a common factor respectively from measuring items of the six kinds of variables (named after the original variable name), so as to realize the dimension reduction of the original index system. Based on this, this paper firstly conducts descriptive statistics of the classification status of all kinds of waste (see table 4); it is easy to see that, as for the recycling categories of waste, the population with a high frequency of waste paper/paper plate accounts for the highest number of (58. 22\%); kitchen waste follows; the proportion of high frequency classification of discarded plastic bottles and discarded cans was over $50 \%$; the proportion of discarded glass bottles was the lowest (41.91\%). Among them, the waste paper/paper board, waste plastic bottles and cans are of high recovery value; waste glass bottles have a lower market value because of high cost in reproduction and small renewable profit, which 
are not accepted by recycling acquisition merchants. Kitchen waste is the emphasis of the classification in current community propaganda.

Table 4 Relevant description information of various types of waste

\begin{tabular}{|c|c|c|c|c|c|c|}
\hline \multirow[b]{2}{*}{ Type of waste } & \multicolumn{6}{|c|}{ Classification frequency $(\%)$} \\
\hline & $1^{\mathrm{A}}$ & 2 & 3 & 4 & 5 & $\begin{array}{l}\text { High } \\
\text { classification } \\
\text { frequency }^{\mathrm{B}}\end{array}$ \\
\hline $\begin{array}{l}\text { Waste paper/ waste } \\
\text { paper board }\end{array}$ & 6.47 & 11.99 & 23.32 & 32.61 & 25.61 & 58.22 \\
\hline \begin{tabular}{lr}
\multicolumn{1}{c}{ Disused } & $\begin{array}{r}\text { batteries } \\
\text { electronic }\end{array}$ \\
and & \\
equipment. &
\end{tabular} & 11.46 & 17.12 & 24.66 & 26.82 & 19.95 & 46.77 \\
\hline Kitchen waste & 12.94 & 15.09 & 15.23 & 27.22 & 29.51 & 56.73 \\
\hline Plastic bottle & 10.11 & 15.09 & 21.02 & 29.38 & 24.39 & 53.77 \\
\hline Discarded cans. & 11.32 & 15.36 & 19.95 & 28.57 & 24.8 & 53.37 \\
\hline Scrap metal & 14.69 & 18.19 & 20.49 & 26.28 & 20.35 & 46.63 \\
\hline Renewable plastics & 12.67 & 17.79 & 19.81 & 29.65 & 20.08 & 49.73 \\
\hline Waste glass bottle & 16.44 & 21.16 & 20.49 & 23.85 & 18.06 & 41.91 \\
\hline $\begin{array}{l}\text { Discarded clothing } \\
\text { and textiles }\end{array}$ & 14.96 & 17.12 & 21.83 & 24.26 & 21.83 & 46.09 \\
\hline
\end{tabular}

Table 5 Relevant description information of the classification of various community residents.

\begin{tabular}{|c|c|c|c|c|c|c|}
\hline $\begin{array}{c}\text { Community } \\
\text { groups }\end{array}$ & $\begin{array}{c}\text { Propaganda } \\
<1 \text { year }\end{array}$ & $1-2$ years & $2-3$ years & $>3$ years & $\begin{array}{c}\text { Incentive } \\
\text { policies }\end{array}$ & Community groups \\
\hline $\begin{array}{c}\text { The average score } \\
\text { of residents' } \\
\text { classification } \\
\text { factors. }\end{array}$ & -0.468 & -0.006 & 0.513 & 0.643 & 0.563 & $\begin{array}{c}\text { The average score } \\
\text { of residents' } \\
\text { classification } \\
\text { factors. }\end{array}$ \\
\hline
\end{tabular}

Thus, residents tend to make classification on the waste of high recovery value and with emphasized propaganda, which fully shows that the important impact of policy propaganda education and the informal recycling system. At the same time, through the comparison of average classification factor score of the five community residents (see table 5), we can see that, in the communities with policy propaganda education, the results and overall situation are better in those with longer propaganda time; in the communities with incentive policies, residents normally have higher level in garbage classification. Based on the extracted common factors, this paper applies the STATA12 software and uses the hierarchical regression model to verify the aforementioned assumptions. The model of influencing factors of residents' classification behavior is as follows:

$$
y_{i}=\alpha+\sum_{k=1}^{K} \beta_{k} \chi_{i k}+\sum_{k=1}^{K} \beta_{k} \chi_{i k}+\mu_{i}
$$

yi stands for the degree of resident i participation in garbage sorting; $\alpha$ is model intercept; $\mu_{\mathrm{i}}$ is random disturbance; $x_{i k}$ is the psychological variable of resident $i ; d_{n}$ is policy virtual variable; $z_{i m}$ is the population background characteristic variable of resident $\mathrm{i} ; \beta_{\mathrm{k}}, \gamma_{\mathrm{n}}, \delta \mathrm{m}$ represent the corresponding coefficients of these three independent variables. In the process of regression, this paper firstly carries out multiple co-linear tests. Due to the weak correlation of each factor and the entire variable VIF lower than 10, there are no serious collinearity problems. Secondly, in order to avoid the bias of inspection findings caused by the phenomenon of heteroscedasticity, this paper adopts a robust regression.

\section{Conclusion}

Urban garbage management is a complex and extremely important issue, and the research in the future will be deeper and more specific. Interdisciplinary research teams need to be introduced to make research on this. As a new mode, the recycling point system of urban household garbage sorting plays an important role in household garbage management of Hangzhou city, which is the 
concrete incentive measurement and technique to implement the Circular Economy Promotion Law, Regulations for Urban Household Garbage Measures and other laws and regulations. In view of the difficulties encountered in the classification and recycling of urban household garbage in our country, we can learn from this Hangzhou mode. Due to the restrictions of many conditions, the implementation of garbage classification and recycling point system in Hangzhou has encountered some unavoidable difficulties. Therefore, we should strengthen the legal system construction and enforcement, promote outstanding experience, and develop circular economy, to ensure that recycling point of urban household garbage sorting system achieves remarkable achievement, so as to do a good job in the household garbage management in our country, to improve the protection of the environment, and to promote the development of national cyclic economy, ultimately achieving sustainable development.

\section{References}

[1] Dai Yingchun. Status of Urban Household Garbage Classification in China [J]. Environmental Sanitation Engineering,2016,24(06):1-4.

[2] Xu Lin, Ling Maoliang, Lu Yujie. Study on the Influence Factors of Urban Residents' Garbage Classification [J]. Journal of Public Administration,2017,14(01):142-153+160.

[3] Zhang Jinsong. Study on Compulsory Classification of Urban Household Garbage [J]. Theoretical Exploration,2017(04):99-104.

[4] Zang Xiuqing. Study on Classification and Disposal of Urban Household Garbage in Qinhuangdao [J]. Economic Forum,2015(02):28-32.

[5] Zhang Liping, Zhang Zhonghua. The Dilemma and Overcoming of the Collective Action of Residents in the Source Classification of Urban Household Garbage [J]. Journal of Wuhan University (Philosophy and social science edition),2016,69(06):50-56. 